Ambiente \& Água - An Interdisciplinary Journal of Applied Science
ISSN 1980-993X - doi:10.4136/1980-993X
www.ambi-agua.net
E-mail: ambi.agua@gmail.com

\title{
High concentrations of toxic metals in water consumed by the Maxakali indigenous community in Brazil
}

\author{
ARTICLES doi:10.4136/ambi-agua.2215
}

Received: 23 Nov. 2017; Accepted: 12 Nov. 2018

\section{Eliseu Miranda de Assis ${ }^{1 *(D)}$; Maicon Junior dos Santos Souza ${ }^{2}$; Márcia Cristina da Silva Faria ${ }^{2}$; Jairo Lisboa Rodrigues ${ }^{2}{ }^{D}$; Anderson Garcez ${ }^{1}$; Cleide Aparecida Bomfeti ${ }^{-1 D}$; Nêmora Tregnago Barcellos ${ }^{1}$ iD}

\author{
${ }^{1}$ Universidade do Vale do Rio dos Sinos (Unisinos), São Leopoldo, RS, Brasil \\ Programa de Pós-graduação em Saúde Coletiva. E-mail: eliseumiranda@ifba.edu.br, \\ adsgarcez@gmail.com,nemoratb@gmail.com \\ ${ }^{2}$ Universidade Federal dos Vales do Jequitinhonha e Mucuri (UFVJM), Teófilo Otoni, MG, Brasil \\ Instituto de Ciência, Engenharia e Tecnologia (ICET). E-mail: maiconjunior.ufvjm@ @otmail.com, \\ marcia.faria@ufvjm.edu.br, jairo.rodrigues@ufvjm.edu.br, cleide.bomfeti@ufvjm.edu.br \\ *Corresponding author
}

\begin{abstract}
The Maxakali is the second largest indigenous population in the state of Minas Gerais, Brazil; and parasitic diseases are its main cause of death. Problems related to the quality of water consumed by this population, added to the absence of public sanitation services, aggravate the risk of illnesses due to several water-borne pathologies. Thus, the main purpose of this paper was to evaluate the water quality consumed in natura by the Maxakali community, quantifying toxic metals in relation to the maximum values allowed by Brazilian law. A descriptive cross-sectional study was carried out with samples of water collected in surfaceand groundwater in the Maxakali villages, including three seasonal periods. Villages with the greatest number of altered measures of metals in water were Aldeias Pradinho (100\%) and Água Boa (92\%). The smallest number of changes were found in Aldeias Verde and Rafael (27\%). The metals that appeared in the largest number of collections with values higher than recommended were Iron (50\%), followed by Arsenic (46\%), Aluminum (36\%), Cadmium $(22 \%)$ and Mercury (20\%), respectively. The study identified high concentrations of toxic metals in the water consumed by the Maxakali indigenous community in Brazil.
\end{abstract}

Keywords: Maxakali Indians, surface and underground water, toxic metals, water quality.

\section{Concentrações elevadas de metais tóxicos na água consumida pela comunidade indígena Maxakali no Brasil}

\section{RESUMO}

O povo Maxakali é a segunda maior população indígena aldeada no Estado de Minas Gerais, Brasil, tendo nas doenças infecciosas e parasitárias, sua principal causa de morte. Problemas com a qualidade da água consumida por essa população, somados à ausência dos serviços públicos de saneamento, agravam o risco de adoecimento por diversas patologias de veiculação hídrica. Assim, um estudo descritivo de desenho transversal, com amostras de água coletadas em locais de captação para consumo, foi realizado nas aldeias em três períodos 
sazonais, com objetivo de avaliar a água consumida, através da quantificação de metais tóxicos em relação aos valores máximos permitidos na legislação brasileira. As aldeias com maior número de medidas alteradas de metais na água foram, a Aldeia Pradinho (100\%), seguida de Água Boa (92\%). Os menores números de alterações foram encontrados nas Aldeias Verde e Rafael (27\%). Os metais que apareceram em maior número de amostras com valores acima do recomendado foram o Ferro (50\%), seguido do Arsênio (46\%), Alumínio (36\%), Cádmio (22\%) e o Mercúrio (20\%). Dessa forma, este estudo identificou altas concentrações de metais tóxicos na água consumida pelas comunidades indígenas de Maxakali no Brasil.

Palavras-chave: água superficial e subterrânea, índios Maxakali, metais tóxicos, qualidade da água.

\section{INTRODUCTION}

The Maxakali are the second largest indigenous population in the State of Minas Gerais, located in the Southeast region of Brazil, including approximately 2020 individuals (Brasil, 2015). Although they live in villages, the Maxakali indigenous community travels through several cities in the Northeast of the state, between the Mucuri, Jequitinhonha and Rio Doce valleys. In this region, the advance of agriculture and livestock, as well as the inadequate occupation of the soil close to springs and the large hydrographic basins have favored the emergence of potential toxins in these environments, which contaminate the natural reservoirs and greatly impact human health and local flora and fauna (Derisio, 1992). In addition, the hydrographic basins where Maxakali villages are located have received large loads of waste from anthropic activities due to the disorderly urban development, such as the in natura discharge of industrial and domestic sewage from the cities that make up this micro region (Blanc et al., 2013).

The indigenous people usually consume fresh water, taking into account visual, olfactory and palatability characteristics. However, the senses that evaluate the quality of water used for human consumption, which identify organoleptic characteristics that express taste, color and odor, may not reveal the actual sanitary water condition. This fact, coupled with the precariousness of the public sanitation services, which determine the lack of systematic evaluations and the guarantee of minimum standards of potability, aggravates the risk of waterborne diseases in this vulnerable population group due to nutritional and parasitic conditions (Borges et al., 2009; Assis et al., 2013). In this sense, the risk of consumption of fresh water in Maxakali indigenous communities is evidenced by the high presence of intestinal parasites in this population (Assis et al., 2013). In addition, a recent study identified high concentrations of toxic metals in rivers and tributaries near the regions of the Maxakali villages (Blanc et al., 2013).

Although there are Brazilian standards to evaluate the quality of consumed water, including an Ordinance of The Brazilian Ministry of Health, and resolutions from The National Council of the Environment - CONAMA, there is a lack of public policies of sanitation and water quality monitoring, especially in rural communities where social, educational and health programs are extremely precarious. This context shows the need of wide-ranging studies of the quality of the water for consumption, especially for concentrations of highly toxic heavy metals, capable of irritating the skin and causing gastrointestinal disorders, neurological disorders and carcinogenesis (Melville and Burchett, 2002). In addition, the concentration of heavy metals has not yet been used to evaluate the quality of the raw water utilized for public drinking water supplies in Brazil (Bollmann and Marques, 2000). This study therefore evaluated the concentrations of toxic metals in surface water and underground water consumed in natura by the Maxakali indigenous community in Brazil, including three seasonal periods. 


\section{MATERIALS AND METHODS}

A cross-sectional descriptive study was conducted, including water samples collected in three seasonal periods from all official and unofficial sources of water consumed by the indigenous Maxakali community. The study was carried out on the Maxakali lands, located in the northeast region of the State of Minas Gerais, Southeast region of Brazil (Figure 1).

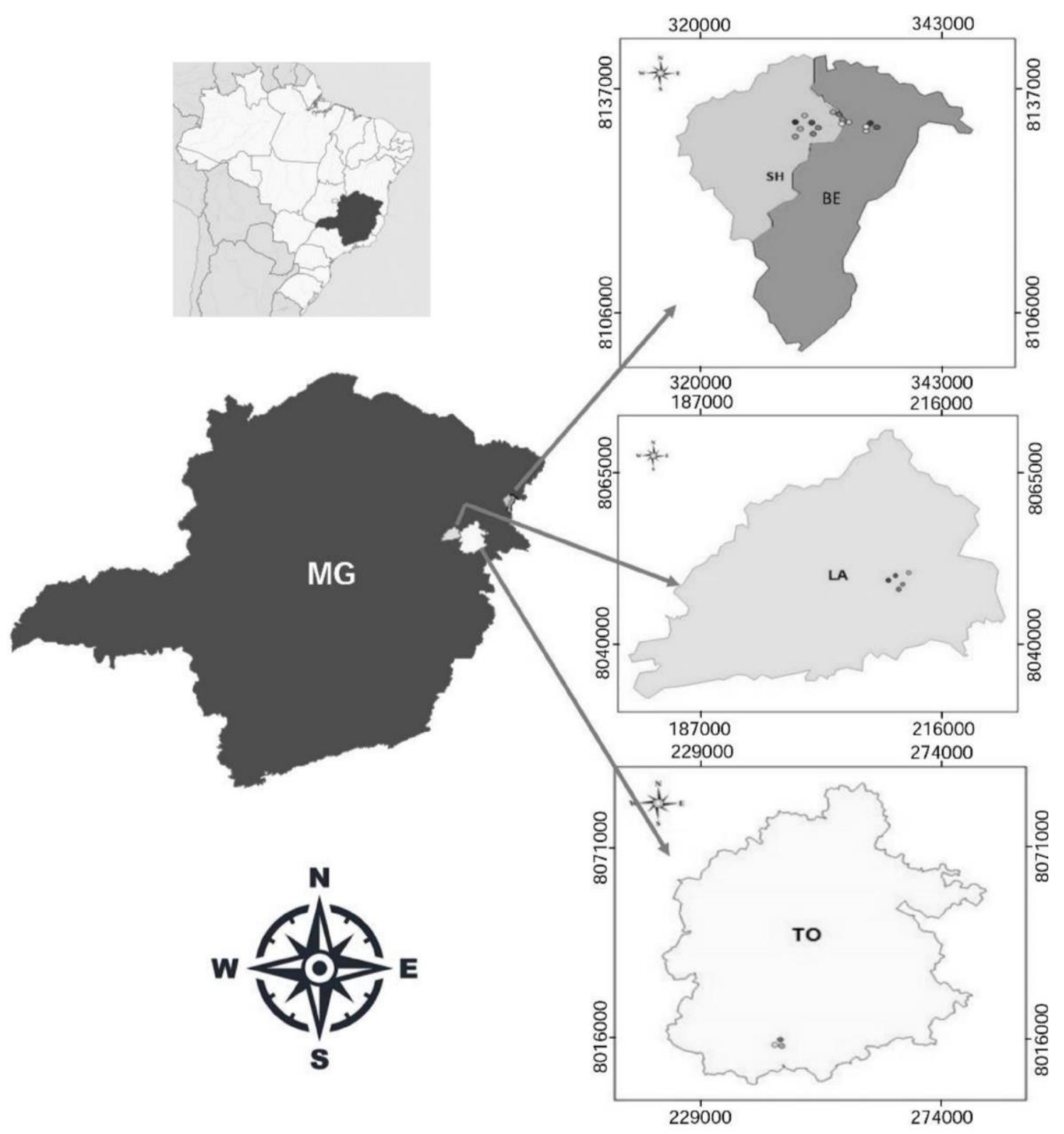

Figure 1. Location of the study area with collection points in the four Maxakali indigenous villages, Minas Gerais, Brazil. MG: state of Minas Gerais (Brazil), SH: city of Santa Helena de Minas, BE: city of Bertópolis, LA: city of Ladainha, TO: city of Teófilo Otoni (district of Topázio).

The territory corresponds to the villages of Água Boa (city of Santa Helena de Minas), Pradinho/Vila Nova (city of Bertópolis/MG), Aldeia Verde (city of Ladainha) and Aldeia Cachoeirinha/Rafael in Topázio district (city of Teófilo Otoni/MG). The Aldeia Pradinho (Vila Nova) and Aldeia Água Boa are located in an area of approximately 5,305 hectares. Hydrographically, these two indigenous lands that are largest in territorial extension and in population, are located in the headwaters of Itanhém River tributaries, the Itanhém River Basin, 
which flows into the Atlantic Ocean at the city of Alcobaça/BA. They belong politically and administratively to the region of Mucuri Valley, in the Northeast region of Minas Gerais. Aldeia Verde is located in the city of Ladainha/MG, occupying 552 hectares, where hills and low soil fertility predominate (Carvalho, 2000). Aldeia Cachoeirinha (Aldeia de Rafael), in Topázio, district of Teófilo Otoni/MG, has been in existence for less than nine years with poor road infrastructure and lack of sanitation. Both Aldeia Verde and Aldeia Rafael are located in the Mucuri River Basin.

Twenty-four points were mapped (nine in Aldeia Pradinho/Vila Nova, seven in Aldeia Água Boa, five in Aldeia Verde and three in Aldeia Rafael/Cachoeirinha): four artesian wells, five reservoirs, six ends of the water network, a river, five streams, two lagoons and a water spring. (Supplementary Table 1 S1) shows the description of the points mapped, including the geodetic coordinates information. The five freshwater streams are mostly born within the boundaries of the villages. In drought periods, these streams can be considered as lentic environment with almost stagnant water, classified as Class II (intended for domestic supply after conventional treatment). However, due to the in natura consumption at times of recreation and fishing activities, they were classified as Class I (water used for domestic supply after simplified treatment) for evaluation purposes. The freshwater river (lotic environment) is born outside the boundaries of the village and was classified as Class I, since it is consumed in natura. This river receives a moderate load of domestic sewage coming from farms and the town of Oropinha in the district of Santa Helena de Minas/MG, before passing through the village.

Sample collection and preservation, including all quality assurance and quality control procedures, strictly followed the protocols recommended by the Environmental Sanitation Technology Company of São Paulo (Companhia de Tecnologia de Saneamento Ambiental) (CETESB, 2011). Samples were collected and identified in $50 \mathrm{ml}$ of metal-free polypropylene bottles (Falcon BD $®)$, stored in temperature-controlled thermal boxes and immediately sent for processing. Prior to sample collection, our group ruled out the presence of any kind of metal in the polypropylene bottles used in this study, including mercury. All reagents used in the cleaning procedure of the sampling material were analytical-reagent grade, including nitric acid 65\% (HNO3) obtained from Sigma Aldrich ${ }^{\circledR}$. High-purity deionized water (resistivity 18.2 M $\Omega$ $\mathrm{cm}-1$ ) obtained using a Milli-Q water purification system (Millipore, Bedford, MA, USA) was also used throughout. All solutions were stored in high-density polyethylene bottles. Plastic materials were cleaned by soaking in $10 \%$ (v/v) HNO3 for 48 hours, rinsed five times with Milli-Q water and dried in a Class 100 laminar flow hood before use. All operations were performed on a clean bench. Multi-element stock solutions containing $1000 \mathrm{mg} \mathrm{L}-1$ of each element were obtained from Perkin-Elmer (PerkinElmer, Norwalk, CT, USA).

The sample collection was made at three times, with a seasonal criterion including dry, intermediate and rainy periods. The first collection occurred in January 2015, considered the rainy period for the region by the weather forecast. However, in that period there was no rain. The second collection was carried out in April 2015, considered the intermediate period by the weather forecast when the temperatures were mild, still without voluminous rains, but with discreet precipitations, insufficient to recharge the rivers, streams and wells. The third collection was in July 2015, under heavy rains, although the weather report had announced a dry period. The climatic variations did not impact the study, since it was intended to evaluate moments of greater dilution favored by rain and lower dilution favored by the drought.

Metals and semi-metals concentrations were evaluated, including: aluminum, arsenic, barium, cadmium, lead, copper, chromium, iron and mercury, and their respective cut points were considered altered when they reached the Maximum Permitted Values (MPV) for each element above acceptable for surface and groundwater, taking into consideration the ordinance of the Ministry of Health 2914/2011 and The National Council of the Environment - CONAMA 
resolutions 357/2005 and 396/2008. For the definition of normal or altered quantities, all reference values have been converted into units of micrograms per liter $(\mu \mathrm{g} / \mathrm{l})$ since some MPVs refer to $\mathrm{mg} / \mathrm{L}$ unit. For the determination of metals, the analytical method proposed by Lawrence et al. (2006) was used. The analyzes were processed in a Clean Room Class 1000 based on the water analysis method 200.8 PerkinElmer (Pruszkowski and Bosnak, 2012), using an inductively coupled plasma mass spectrometer (ICP-MS) NexIon 300D (USA). Quality control for the determination of metals in the water samples was carried out via analysis of water standard reference materials (Aluminum, Arsenic, Barium, Cadmium, Chromium, Copper, Iron, Lead) from the National Institute of Standards and Technology (NIST 1640a, Trace Elements in Natural Water; NIST 1643e, Trace Elements in Water; and NIST 1641e, Mercury in water). The reference samples were analyzed before and after ten runs of ordinary water samples. There were no statistical differences between the concentration values obtained for the reference materials and the "target-values" for $95 \%$ confidence intervals using the Ttest. These results confirm the accuracy of the method. In study of the precision (intra-day and inter-day precision) the relative standard deviation (RSD) was less than $1.8 \%$ (intra-day precision) and less than $2.0 \%$ (inter-day precision) for all elements analyzed.

Statistical analyses were conducted with the main objective of comparing the concentration levels of toxic metals. The results were typed (double entry and correction of inconsistencies) in the SPSS Software, Version 22 (SPSS Inc., Chicago, IL, EUA). Variables were created for each cutoff point in relation to the MPV. The Student's t-test for comparison of metal concentration averages was used, including the respective 95\% confidence intervals (CI 95\%), and comparative analysis of the results was obtained with the reference values provided by literature. Statistical analyses were performed in relation to the collection point, village, seasonality and the origin of the water (superficial or underground).

This study was submitted and approved (protocol number 129/2015) by the Ethics and Research Committee of the University of Vale do Rio do Sinos - UNISINOS. Indigenous leaderships and the Special Indigenous District of Minas Gerais / Espirito Santo have also approved this research.

\section{RESULTS AND DISCUSSION}

Regarding the origin of the water, 10 points (42\%) were groundwater and $14(58 \%)$ of surface water, most of them artesian wells or dams made in springs. The artesian wells sampled had depths between 30 and 120 meters, with flows from 2500 to 8300 1/hour. The connections and pipelines were galvanized, and water belonging to Class I by resolution CONAMA 375/2005. The five reservoirs with 13 storage units were mostly PVC boxes with a capacity of 15 thousand liters and the rest were the iron base with capacity of more than 20 thousand liters.

In the general context, Aldeia Verde and Rafael were the ones that presented the smallest changes in the dosage of the evaluated metals. All the evaluated metals had their values changed at some point in the study in Aldeia Pradinho. Similar results were found in Aldeia Água Boa, where eight of the nine evaluated elements disagreed with the standards established for human consumption (Table 1). When individualized, the aluminum presented values above the maximum allowed limit in 14 of the 24 evaluated points. In the dry period, its minimum concentration was 25.16 micrograms per liter $(\mu \mathrm{g} / \mathrm{L})$ and its maximum concentration was 49,206 $(\mu \mathrm{g} / \mathrm{L})$, at point AP4 at the Aldeia Pradinho, representing an increase of more than 200 times in relation to MPV (100 $\mu \mathrm{g} / \mathrm{L}$ for surface water and $200 \mu \mathrm{g} / \mathrm{L}$ for groundwater). (Supplementary Table 2 S2) shows the analytical results in trace metals concentrations $(\mu \mathrm{g} / \mathrm{L})$ in the three seasonal periods at twenty-four collection points in Maxakali Villages. 
Table 1. Number and percentage of analyzes of metals and semimetals with a dosage above that allowed for consumption in the Maxakali villages, Minas Gerais, Brazil.

\begin{tabular}{|c|c|c|c|c|c|c|c|c|}
\hline \multirow{3}{*}{ Metals } & \multicolumn{8}{|c|}{ Villages } \\
\hline & \multicolumn{2}{|c|}{ Pradinho } & \multicolumn{2}{|c|}{ Água Boa } & \multicolumn{2}{|c|}{ Verde } & \multicolumn{2}{|c|}{ Rafael } \\
\hline & $(\mathrm{a} / \mathrm{C})(\%)$ & Min/Max & $(a / C)(\%)$ & Min/Max & $(\mathrm{a} / \mathrm{C})(\%)$ & Min/Max & $(\mathrm{a} / \mathrm{C})(\%)$ & Min/Max \\
\hline Al & $06 / 27(22)$ & $124.3 / 49206$ & 04/21 (19) & 101.2/7238.8 & $10 / 15(67)$ & $100.9 / 828.3$ & 06/09 (67) & $106.9 / 131.59$ \\
\hline As & $10 / 27(37)$ & $15.3 / 182.1$ & $07 / 21(33)$ & $152.2 / 166.8$ & $10 / 15(67)$ & $143.6 / 169.4$ & 06/09 (67) & $144.2 / 154.9$ \\
\hline $\mathbf{B a}$ & $02 / 27(7.4)$ & $4.23 / 956.5$ & 04/21 (19) & $2.9 / 236.6$ & - & $<\mathrm{LQO}$ & - & $<\mathrm{LQO}$ \\
\hline Cd & $09 / 27(33)$ & $5.07 / 5.15$ & $07 / 21(33)$ & $5.07 / 5.08$ & - & $<$ LQO & - & $<\mathrm{LQO}$ \\
\hline $\mathrm{Cr}$ & $01 / 27(3.7)$ & 56.9 & - & $<\mathrm{LQO}$ & - & $<\mathrm{LQO}$ & - & $<\mathrm{LQO}$ \\
\hline $\mathbf{C u}$ & $02 / 27(7.4)$ & $11.04 / 37.8$ & $02 / 21(9.5)$ & $11.4 / 13.7$ & - & $<$ LQO & - & $<\mathrm{LQO}$ \\
\hline $\mathbf{F e}$ & $16 / 27(59)$ & $623.1 / 88664.7$ & $12 / 21(57)$ & $323.9 / 25078.1$ & $04 / 15(27)$ & $303.4 / 13173.5$ & $04 / 09$ (44) & $452.9 / 13252.5$ \\
\hline $\mathbf{H g}$ & 08/18 (44) & $2.8 / 17.9$ & $07 / 14(50)$ & $13.6 / 14.26$ & - & $<\mathrm{LQO}$ & - & $<\mathrm{LQO}$ \\
\hline $\mathbf{P b}$ & $03 / 27(11)$ & $11.4 / 52.1$ & $01 / 21(4.7)$ & 12.5 & - & $<$ LQO & - & $<\mathrm{LQO}$ \\
\hline
\end{tabular}

Al-Aluminum, As-Arsenic, Ba-Barium, Cd-Cadmium, Cu-Copper, Cr-Chromium, Fe-Iron, Hg-Mercury, Pb-Lead, a- number of altered analyzes, Cnumber of collections which were made, $(-)<$ LQO below the limit of quantification, Min - minimum value observed in the samples, Max - maximum value observed in the samples. 
In Aldeia Pradinho (AP), some changes were identified at points AP4, AP5 and AP6. In Aldeia Água Boa (AB), the changes were visible at points $A B 1, A B 4, A B 5$ and AB7, with emphasis on the value that was found at point AB4 in the dry period $(7238,83 \mu \mathrm{g} / \mathrm{L})$. In Aldeia Verde (AV), there were changes in four of the five evaluated points, with little variation in relation to seasonality. Points AV1, AV2, AV4 and AV5 presented concentrations above the recommended limit, although in most of them, those values were very close to the acceptable limit. The same happened in Aldeia Rafael (AR) in the intermediate and rainy periods, except in the dry period (Table 2).

Table 2. Number of collections and metals with above permitted dosage, according to seasonality, for consumption in the Maxakali Villages, Minas Gerais, Brazil.

\begin{tabular}{|c|c|c|c|c|c|c|c|c|c|c|c|}
\hline \multirow[b]{2}{*}{ Villages } & \multicolumn{11}{|c|}{ Metals } \\
\hline & Points & $\mathbf{A l} *$ & As* & $\mathbf{B a}^{*}$ & $\mathbf{C d}^{*}$ & $\mathrm{Cu}^{*}$ & $\mathrm{Cr}^{*}$ & $\mathbf{F e}^{*}$ & $\mathbf{H g}^{* * *}$ & $\mathbf{P b} *$ & $\begin{array}{c}\text { Total metals with } \\
\text { change at each } \\
\text { point }(\mathrm{N}-9)\end{array}$ \\
\hline \multirow{9}{*}{ Pradinho } & AP1 & - & $2(\mathrm{I})$ & - & $1(\mathrm{C})$ & - & - & $2(\mathrm{~S} / \mathrm{C})$ & $1(\mathrm{C})$ & $1(\mathrm{C})$ & 5 \\
\hline & AP2 & - & $1(\mathrm{I})$ & - & $1(\mathrm{C})$ & - & - & $1(\mathrm{~S})$ & - & - & 3 \\
\hline & AP3 & - & $1(\mathrm{I})$ & - & $1(\mathrm{C})$ & - & - & $1(\mathrm{~S})$ & $1(\mathrm{C})$ & - & 3 \\
\hline & AP4 & $1(\mathrm{~S})$ & 1(I) & $1(\mathrm{~S})$ & $1(\mathrm{C})$ & $1(\mathrm{~S})$ & $1(\mathrm{~S})$ & $2(\mathrm{~S} / \mathrm{C})$ & $1(\mathrm{C})$ & $1(\mathrm{~S})$ & 9 \\
\hline & AP5 & $3(\mathrm{~S} / \mathrm{I} / \mathrm{C})$ & $1(\mathrm{I})$ & $1(\mathrm{~S})$ & $1(\mathrm{C})$ & - & - & $2(\mathrm{~S} / \mathrm{C})$ & $1(\mathrm{C})$ & $1(\mathrm{~S})$ & 7 \\
\hline & AP6 & $2(\mathrm{I} / \mathrm{C})$ & $1(\mathrm{I})$ & - & $1(\mathrm{C})$ & $1(\mathrm{C})$ & - & $1(\mathrm{~S})$ & $1(\mathrm{C})$ & - & 6 \\
\hline & AP7 & - & $1(\mathrm{I})$ & - & $1(\mathrm{C})$ & - & - & $3(\mathrm{~S} / \mathrm{I} / \mathrm{C})$ & $1(\mathrm{C})$ & - & 4 \\
\hline & AP8 & - & $1(\mathrm{I})$ & - & $1(\mathrm{C})$ & - & - & $2(\mathrm{~S} / \mathrm{C})$ & $1(\mathrm{C})$ & - & 4 \\
\hline & AP9 & - & 1(I) & - & $1(\mathrm{C})$ & - & - & $2(\mathrm{~S} / \mathrm{C})$ & $1(\mathrm{C})$ & - & 4 \\
\hline \multirow{7}{*}{ Água Boa } & $\mathrm{AB} 1$ & $1(\mathrm{C})$ & 1(I) & - & $1(\mathrm{C})$ & - & - & $2(\mathrm{~S} / \mathrm{C})$ & $1(\mathrm{C})$ & $1(\mathrm{C})$ & 6 \\
\hline & $\mathrm{AB} 2$ & - & $1(\mathrm{I})$ & - & $1(\mathrm{C})$ & - & - & $2(\mathrm{~S} / \mathrm{C})$ & $1(\mathrm{C})$ & - & 4 \\
\hline & $\mathrm{AB} 3$ & - & $1(\mathrm{I})$ & - & $1(\mathrm{C})$ & - & - & $2(\mathrm{~S} / \mathrm{C})$ & $1(\mathrm{C})$ & - & 4 \\
\hline & $\mathrm{AB} 4$ & $1(\mathrm{~S})$ & $1(\mathrm{I})$ & $1(\mathrm{~S})$ & $1(\mathrm{C})$ & - & - & $1(\mathrm{~S})$ & $1(\mathrm{C})$ & - & 6 \\
\hline & AB5 & $1(\mathrm{I})$ & 1(I) & $1(\mathrm{~S})$ & $1(\mathrm{C})$ & - & - & $1(\mathrm{~S})$ & $1(\mathrm{C})$ & - & 6 \\
\hline & AB6 & - & 1(I) & $1(\mathrm{~S})$ & $1(\mathrm{C})$ & $1(\mathrm{C})$ & - & $2(\mathrm{~S} / \mathrm{C})$ & $1(\mathrm{C})$ & - & 7 \\
\hline & $\mathrm{AB} 7$ & 1(I) & $1(\mathrm{I})$ & $1(\mathrm{~S})$ & $1(\mathrm{C})$ & $1(\mathrm{C})$ & - & $2(\mathrm{~S} / \mathrm{C})$ & $1(\mathrm{C})$ & - & 7 \\
\hline \multirow{5}{*}{ Verde } & AV1 & $2(\mathrm{I} / \mathrm{C})$ & $2(\mathrm{I} / \mathrm{C})$ & - & - & - & - & $1(\mathrm{~S})$ & - & - & 3 \\
\hline & AV2 & $2(\mathrm{I} / \mathrm{C})$ & $2(\mathrm{I} / \mathrm{C})$ & - & - & - & - & - & - & - & 2 \\
\hline & AV3 & - & $2(\mathrm{I} / \mathrm{C})$ & - & - & - & - & $1(\mathrm{~S})$ & - & - & 2 \\
\hline & AV4 & $3(\mathrm{~S} / \mathrm{I} / \mathrm{C})$ & $2(\mathrm{I} / \mathrm{C})$ & - & - & - & - & $1(\mathrm{~S})$ & - & - & 3 \\
\hline & AV5 & $3(\mathrm{~S} / \mathrm{I} / \mathrm{C})$ & $2(\mathrm{I} / \mathrm{C})$ & - & - & - & - & $1(\mathrm{~S})$ & - & - & 3 \\
\hline \multirow{3}{*}{ Rafael } & AR1 & 2(I/C) & $2(\mathrm{I} / \mathrm{C})$ & - & - & - & - & 2(I/C) & - & - & 3 \\
\hline & AR2 & $2(\mathrm{I} / \mathrm{C})$ & $2(\mathrm{I} / \mathrm{C})$ & - & - & - & - & $1(\mathrm{~S})$ & - & - & 3 \\
\hline & AR3 & $2(\mathrm{I} / \mathrm{C})$ & $2(\mathrm{I} / \mathrm{C})$ & - & - & - & - & $1(\mathrm{~S})$ & - & - & 3 \\
\hline \multicolumn{2}{|c|}{$\begin{array}{l}\text { Total of altered } \\
\text { measures for each } \\
\text { metal (N 72) }\end{array}$} & 26 & 33 & 06 & 16 & 04 & 01 & 36 & 15 & 04 & \\
\hline
\end{tabular}

Al-Aluminum, As-Arsenic, Barium, Cd-Cadmium, Cu-Copper, Cr-Chromium, Fe-Iron, Hg-Mercury, Lead-Pb / * Collected in triplicate / ** Collected in duplicate. S-dry period; I-intermediate period; Crainfall period, (-) Below the maximum allowable limit or limit of detection of quantification.

Chromium was the element with the lowest percentage of change in relation to the other metals whose values were above the MPV. Only in the drought period, at a single point (AP4) in Aldeia Pradinho, were values detected above those recommended (Table 2). The value (56.97 $\mu \mathrm{g} / \mathrm{L}$ ) was nearly $14 \%$ above the acceptable value in waters used for human consumption (50 $\mu \mathrm{g} / \mathrm{L})$. Regarding iron concentrations, values $(88,664.74 \mu \mathrm{g} / \mathrm{L})$ were observed in the dry period 295 times higher than allowed $(300 \mu \mathrm{g} / \mathrm{L})$. Of 24 evaluated points, 23 had values above the MPV (Table 2). In the intermediate period, in relation to seasonality, values levels remained within the acceptable range. Only $8 \%$ of the samples had values above the MPV. The greatest 
alterations were observed in the dry period, both in relation to the percentage of collections with values above that recommended $(91.6 \%)$ and in relation to their maximum values.

Copper had values changed (above $9 \mu \mathrm{g} / \mathrm{L}$ for surface water and $2000 \mu \mathrm{g} / \mathrm{L}$ for underground water) in four of the 24 analyzed points. Those alterations were only identified in Pradinho and Água Boa Villages (Table 2) and in surface waters (Table 4). These villages are geographically close, sharing the same climatic and geological conditions. Concerning arsenic, all collection points presented alterations in relation to MPV $(10 \mu \mathrm{g} / \mathrm{L})$ in the intermediate period. In the rainy season, this change was smaller, $37.5 \%$ of the samples obtained in two villages (Aldeia Verde and Rafael). During the dry season, the arsenic was within the recommended limits. Concerning concentration, the highest and lowest values were observed in the intermediate period, with a minimum of 13 times and a maximum of 18 times higher than VMP.

Barium presented altered concentrations (above $70 \mu \mathrm{g} / \mathrm{L}$ for surface water and $700 \mu \mathrm{g} / \mathrm{L}$ for groundwater) in six of the 24 points, two in Aldeia Pradinho (AP4 and AP5) and four in Aldeia Água Boa (AB4-AB7), in surface water samples with predominance in the dry period (Table 4). The concentrations of cadmium were altered, with values close to the MPV, in all points of Aldeia Pradinho and Água Boa in the rainy season. The values were within the limits $(1 \mu \mathrm{g} / \mathrm{L}$ for surface water and $5 \mu \mathrm{g} / \mathrm{L}$ for groundwater) in the dry and intermediate periods (Table 2). Concerning lead, changes were observed in four of the 24 points, especially Aldeia Pradinho, where $75 \%$ of collections were found with values higher than recommended (Table 2). In the dry period, there was the highest value of lead $(52.16 \mu \mathrm{g} / \mathrm{L})$, being more than five times higher than allowed $(10 \mu \mathrm{g} / \mathrm{L})$. In the intermediate period, the values of lead were within the limits allowed by the legislation, while in the rainy season this change in relation to MPV was identified at points $\mathrm{AP} 1$ and $\mathrm{AB} 1$. Additionally, mercury presented altered concentrations (above $0.2 \mu \mathrm{g} / \mathrm{L}$ for surface water and $1 \mu \mathrm{g} / \mathrm{L}$ for groundwater) in fifteen of the 24 assessed points in the rainy season, identified in Pradinho and Água Boa Villages. There was no evaluation of the mercury in the dry period, due to calibration problems for this element, during the processing of the sample.

In general, the analysis of the metals showed different results when considering the seasonality. In the dry period, six $(54.5 \%)$ of the 11 studied metals had changes in their concentrations in relation to MPVs. In the rainy season, an even greater change was identified, seven $(63.6 \%)$ of the studied metals were above the MPV. The lowest percentage change occurred in the intermediate period with three $(27.2 \%)$ change of the evaluated metals. The major changes in relation to seasonality were evident for arsenic in the intermediate period, for iron in the dry period and for cadmium in the rainy season. Chromium and barium showed concentrations above those permitted only in the dry period and mercury and cadmium only in the rainy season. Aluminum was detected at high concentrations in all periods of collection; however, in the dry period, its percentage of alteration was lower. The opposite was observed for iron, which presented unusual concentrations in all collected samples in the dry season (Table 3).

In Aldeia Pradinho, the AP4, AP5 and AP6 points presented the greatest changes. The Umburana River (AP4) had its most critical moment in the dry period and presented a lower concentration of the metals which were analyzed in the intermediate period. In Aldeia Água Boa, the most affected points were AB6 and AB7 in the rainy season (Table 2). The AV3 point (artesian well / reservoir health station) in Aldeia Verde was the best-evaluated regarding the quantification of the metals, not necessarily in relation to the toxicity of the evaluated metal (Table 2). 
Table 3. Number and percentage of samples with metals concentration higher than permitted for consumption per seasonal period in the Maxakali Villages, Minas Gerais, Brazil.

\begin{tabular}{lcccccc}
\hline \multirow{2}{*}{ Metals } & \multicolumn{2}{c}{ Dry } & \multicolumn{2}{c}{ Intermediate } & \multicolumn{2}{c}{ Rainy } \\
\cline { 2 - 7 } & $\mathbf{n}(\boldsymbol{\%})$ & Min/Max & $\mathbf{n}(\%)$ & Min/Max & $\mathbf{n}(\%)$ & Min/Max \\
\hline Aluminum & $5(21)$ & $178.9 / 49206$ & $11(46)$ & $100.09 / 158.4$ & $10(42)$ & $102.6 / 424.2$ \\
Arsenic & - & - & $24(100)$ & 143.6182 .1 & $9(37.5)$ & $15.3 / 169.4$ \\
Barium & $6(25)$ & $14.6 / 956.5$ & - & - & - & - \\
Cadmium & - & - & - & - & $16(67)$ & $5.07 / 5.15$ \\
Lead & $2(8)$ & $19.3 / 52.1$ & - & - & $2(8)$ & $11.4 / 12.5$ \\
Copper & $1(4)$ & 37.88 & - & - & $3(12)$ & $11.04 / 13.7$ \\
Chrome & $1(4)$ & 56.9 & - & - & - & - \\
Iron & $22(22)$ & $303.4 / 88664.7$ & $2(8)$ & $662.2 / 2551.1$ & $12(50)$ & $323.9 / 21849.9$ \\
Mercury* & - & - & - & - & $15(62)$ & $2.8 / 17.9$ \\
\hline
\end{tabular}

$\mathrm{n}$ - Number of collections with values higher than recommended, Min - minimum value observed in the samples, Max - maximum value observed in the samples, (-) number below the maximum permissible limit or limit of quantification, * Not evaluated in the dry period.

When comparing to MPVs, concerning water origin (surface or groundwater), we detected increased levels of barium, chromium and copper in surface water. Iron, arsenic, cadmium and mercury presented altered concentrations in both surface and underground waters. Aluminum presented concentrations over those allowed in $100 \%$ of the surface sources and in $25 \%$ of the underground sources. The four observed changes for lead were the same in surface and groundwater. When compared to the average concentration of metals in surface and groundwater, it was observed that aluminum, barium, arsenic and lead had much significantly higher concentrations in surface water sources, while cadmium and mercury concentrations were significantly higher in sources of groundwater (Table 4).

Table 4. Average values found in the analysis of metals in $\mu \mathrm{g} / \mathrm{L}$ by source of water in Maxakali villages, Minas Gerais, Brazil.

\begin{tabular}{|c|c|c|c|c|c|c|c|c|c|}
\hline \multirow{2}{*}{ Metal } & \multicolumn{5}{|c|}{ Source of the spring } & \multicolumn{3}{|c|}{$\begin{array}{l}\text { Maximum Allowable } \\
\text { Value }(\mu \mathrm{g} / \mathrm{L})\end{array}$} & \multirow{2}{*}{ P-Value } \\
\hline & Sup & $\begin{array}{l}\text { Standard } \\
\text { deviation }\end{array}$ & Sub & $\begin{array}{l}\text { Standard } \\
\text { deviation }\end{array}$ & Min/Max & Sup & Sup/Sub & Sub & \\
\hline Al & 1642.96 & 4376.3 & 49.92 & 41.38 & $-15.2 / 16451$ & 100 & - & 200 & $0.045^{*}$ \\
\hline $\mathrm{Cr}$ & 20.27 & 5.08 & 15.30 & 2.79 & $12.05 / 32.49$ & - & 50 & - & 0.117 \\
\hline $\mathrm{Fe}$ & 5156.28 & 8250.5 & 2139.8 & 2253.2 & $-27.7 / 29803$ & - & 300 & - & 0.062 \\
\hline Co & -10.48 & 7.55 & -7.43 & 5.37 & $-17.3 / 6.91$ & 9 & - & 2000 & 0.067 \\
\hline As & 78.07 & 22.75 & 58.46 & 14.39 & $47.95 / 104.51$ & - & 10 & - & $<0.001 *$ \\
\hline Cd & -0.6181 & 0.974 & 0.3340 & 0.763 & $-1.56 / 1.10$ & 1 & - & 5 & $0.006^{*}$ \\
\hline Ba & 61.86 & 87.31 & 46.91 & 15.70 & $13.64 / 333.91$ & 70 & - & 700 & $0.037 *$ \\
\hline Le & 1.56 & 6.26 & 0.9430 & 1.33 & $-2.47 / 19.95$ & - & 10 & - & $0.028 *$ \\
\hline Mc & -12.99 & 9.63 & -6.83 & 6.17 & $-22.43 /-2.11$ & 0.2 & - & 1 & $<0.001 *$ \\
\hline
\end{tabular}

$\mathrm{Al}$ (Aluminum), $\mathrm{Cr}$ (Chrome), $\mathrm{Fe}$ (Iron), Co (Copper), As (Arsenic), Cd (Cadmium), Ba (Barium), $\mathrm{Pb}$ (Lead) and $\mathrm{Hg}$ (Mercury). Sup: water from surface sources, Sub: waters from underground sources. Minminimum observed value, Max-maximum observed value, * Statistical significance for P-value $>95 \%$. Maximum value allowed in relation to Ministry of Health ordinances 2914/2011, CONAMA 357 and 396.

The Maxakali villages with the LOWER quality of waters for consumption in relation to the percentage of alteration in metal concentrations were Aldeia Pradinho (100\%), followed by Aldeia Água Boa (92\%); however, Aldeia Verde and Aldeia Rafael had the best evaluations (27\%). The samples with the highest alterations in relation to MPV were iron (50\%) followed 
by arsenic (46\%), aluminum (36\%), cadmium (22\%) and mercury (20\%). Barium (8.3\%), lead and copper $(5.5 \%)$ and chromium (1.3\%) presented lower percentages. Aluminum, barium, arsenic and lead showed significantly higher concentrations in surface water sources, but concentrations of cadmium and mercury were significantly higher in groundwater sources. Seasonality showed that the rainy season is the one with the highest percentage of collections with values higher than recommended, although their difference in relation to the dry period was small. The sources of water of superficial origin were those ones that presented the largest number of altered analyses, for being less protected. Based on these findings, our study identified high concentrations of toxic metals in the water consumed by the Maxakali indigenous community in Brazil.

The Northeastern region of the state of Minas Gerais has in its lithological area archeanoproterozoic rocks with varied metamorphic degree, with emphasis on lithologies of the Espinhaço Supergrupo and Grupo Macaúbas to the west. Its climate is tropical with the predominance of little rain and high temperatures. The Maxakali indigenous land has as main soil type the dystrophic yellow red podzolic, with some inclusions of shallow littoral soils and rock outcrops. The metals that were found in surface or groundwater may be the result of geochemical processes, of the decomposition of rocks and their weathering, and of natural characteristics such as the atmosphere, rainfall, and soil where they are located. That is why they are present in areas with low anthropogenic activity as suggested by the study. Artificially, its appearance is linked to anthropic sources of industrial, agricultural, mining, urban sewage and other unusual activities near the villages, except for the presence of urban sewage.

The cumulative power of some types of metal elements in human tissues causes their excess in drinking water to pose a serious risk to cellular physiological balance (Santos et al., 2006). Iron, like the other studied metals, has toxic potential from the maximum limit established for consumption. However, for this metal, such limit has been questioned because of the geological characteristics of the Brazilian soil that contain high concentrations that contaminate the aquifers (Carvalho, 2000). Its consumption above the limit value does not seem to have a physiological impact, since the amount required in one day by the human body (5-6 milligrams) would correspond to a consumption of 17 to 20 liters in the concentrations of 0.3 ppm, although its excess may increase the incidence of hematological problems, for example (Brewer, 2009). It is easy to find iron mainly in groundwater due to the dissolution of the ore by the carbon dioxide of the water, a characteristic not confirmed in this study, being justified by the geochemistry of the region. Blanc et al. (2013) obtained similar findings studying waters of rivers that are part of the same watershed. In this sense, high concentrations of iron were possibly responsible for the failure of attempts at chlorination in the water of Aldeia Pradinho according to information from local sanitation authorities.

Exposures to arsenic may occur through air, water and food, and values above the acceptable may be associated with the geological characteristics of rocks. In addition, insecticides, herbicides, fungicides, paints and products used to preserve wood are the main artificial sources for this element (Burguera and Burguera, 1993). The toxic potential of arsenic is dependent on the form of presentation in the middle, being a limitation in our study, since we didn't analyze its form of presentation.

In Brazil, studies evaluating the concentration of aluminum in waters of indigenous communities are scarce, although studies in river waters in the watershed region where the villages are located have found high concentrations for this element (Blanc et al., 2013). Regarding cadmium, a natural constituent of oceanic waters and of the earth crust, appears naturally in places that contain other elements such as zinc, lead and copper (Lalor, 2008). Its concentration in the water is naturally low and altered by anthropic conditions. Our findings identified such tendency in the rainy season with values close to the MPV.

The mercury comes from the degradation of the Earth's crust from volcanic eruptions, 
natural evaporation and mercury mines. It is generally associated with other elements and their anthropic sources are diversified (Horvat et al., 1996). Its organic form is the most toxic one and causes damage to human health. The indigenous and coastal communities that consume a lot of fish, present greater exposure to mercury (Lebel et al., 1998). Although some researchers have shown high levels of mercury in Amazonian indigenous populations (Santos et al., 2003), our study was limited to quantify their presence in the water consumed, without evaluating the concentration in the population who lives in the studied areas and its possible repercussion to those people's health.

Depending on the leach content of rocks, barium occurs naturally in surface and groundwater, and its artificial appearance is a result of mining activities and treatment of barium ores, burning of fossil fuels, purification of barite, and use of various insecticides (Mertz, 2012). In our study, the appearance of concentrations above that allowed for human consumption seems to be justified by natural conditions related to soil, which does not limit its potential for toxicity. Lead occurs naturally in small concentrations in the Earth's crust. It can also travel long distances in the air and contaminate areas with little anthropic activity (Patrick, 2006). Even appearing in a lower percentage in this study, it deserves special attention considering its high toxicity. We did not observe anthropic characteristics that could justify the alterations for this element, even though most of the findings showed values close to that recommended. New studies are suggested for the evaluation of this element.

As we know, copper and chromium are widely distributed in nature and it can be found in rocks, soil, water and air. In low doses, copper is essential to health (Gaetke and Chow, 2003). However, the exposure to high levels of copper causes irritation of the mouth, eyes and nose, as well as gastrointestinal distress and death (Santos, 2015). Its artificial appearance in the environment is related to its use in agriculture, in the treatment of water, and in forest fires (Flemming and Trevors, 1989). There was a coincidence of collections with some fires in the forests of Maxakali villages, which may justify the appearance of this element in higher concentrations in the water which was evaluated.

To our knowledge, this is the first study to address the concentration of metals in waters for human consumption in this population group. Although there is no record of hospital admissions due to causes associated with metal toxicity (Brasil, 2015), such absence does not necessarily imply non-existence. Toxicity is characterized by nonspecific symptoms; effects of low doses are underestimated and there is a lack of infrastructure to diagnose possible intoxications. In addition, some social determinants with an isolation in regions distant from access to mass public policies, associated with specific cultural characteristics, place indigenous groups in a condition of high vulnerability (Marmot, 2007).

The indigenous health needs, individual or collective, are influenced by biological, cultural, economic, political and social variables (Nakamura et al., 2009), which causes the impact of vulnerability in facing the differences. Thus, both extrinsic and intrinsic vulnerability present in these groups can promote biological inequalities in health compared to other, less vulnerable groups (Rogers and Ballantyne, 2008). In this sense, it is possible to infer that high concentrations of toxic elements can produce different results in the human organism, depending on the degree of vulnerability to which the receptor is subjected, because the organic response to the aggressive agent may be dependent on biological conditions that should be equal, but that vulnerability makes it different.

Health teams at both local and regional level should be aware of possible clinical symptoms related to poisoning processes by these metals. Health promotion and prevention of diseases, however, cannot wait for symptoms and clinical signs to realize that the water consumed is toxic, especially in places where access to health services is limited. Our study aims to identify the a priori risk and points out the need to establish proposals and measures to minimize risks related to the supply of this water, to be offered by the sanitation team together with responsible 
authorities, taking into consideration the quality of water and the capacity of each point in meeting those local needs. The principle of integrality of caring presupposes that managers also care about the effects of actions on the environment and how to minimize exposure to risk, especially in the context of highly vulnerable populations.

The cultural relationship of the Maxakali people with water, the lack of distinction between contact and consumption and the constant mobility between villages, favors consumption at more critical points, not guaranteeing the absence of risk, even in villages with better indicators. Moreover, because of their cumulative power in plants and aquatic animals, toxic metals can pose a health risk in groups dependent on this food base (Melville and Burchett, 2002). Although our study has presented a worrying scenario regarding the water consumed by Maxakali population, the non-identification of the presentation of some metals makes it difficult to associate them with the risks represented by elements whose absorption and bioavailability depends on this chemical form. Finally, we emphasize that our findings have a scientific importance; however, they must be interpreted in light of the relative limitations in the performance some risk analyses and in analyzing the metal concentrations by the type of water source. This was not possible and indicated considering the logistics of the study, and because the Maxakali indigenous community showed no differentiation in relation to water consumption, justifying the classification of all water sources as Type I accordingly the CONAMA 375/2005 resolution in our study.

\section{CONCLUSIONS}

This study identified high concentrations of toxic metals in the water consumed by the Maxakali indigenous community in Brazil. Due to the higher concentrations for iron, arsenic, aluminum, cadmium and mercury observed in this study, the monitoring of these elements is advisable, besides a generalized identification of their origin. It is also recommended that they be evaluated at smaller intervals in relation to different sources, seasonality and bioavailability of each metal. In addition, it is necessary to search for new water sources with better conditions for this population, besides immediate intervention concerning sources with more critical indicators.

\section{REFERENCES}

ASSIS, E. M.; OLIVIERIA, R. C.; MOREIRA, L. E.; PENA, J. L.; RODRIGUES, L. C.; MACHADO-COELHO, G. L. L. Prevalência de parasitos intestinais na comunidade indígena Maxakali, Minas Gerais, Brasil, 2009. Cadernos de Saúde Pública, v. 29, n. 4, p. 681-690, 2013. http://dx.doi.org/10.1590/S0102-311X2013000400006

BLANC, L. R.; MOREIRA, F. S.; GONÇALVES, A. M.; MANCHESTER, R. S.; BARONI, L.; FARIA, M. C. et al. Contamination in a brazilian river: a risk of exposure to untreated effluents. Journal of Environmental Quality, v. 42, n. 5, p. 1596-1601, 2013. http://dx.doi.org/10.2134/jeq2013.02.0068

BOLLMANN, H. A.; MARQUES, D. M. Bases para a estruturação de indicadores de qualidade de águas. Revista Brasileira de Recursos Hídricos, v. 5, n. 1, p. 37-60, 2000. http://dx.doi.org/10.21168/rbrh.v5n1.p37-60 
BORGES, J. D. B.; ALARCÓN, R. S. R.; AMATO NETO, V.; GAKIYA, E. Parasitoses intestinais de indígenas da comunidade Mapuera (Oriximiná, Estado do Pará, Brasil): elevada prevalência de Blastocystis hominis e encontro de Cryptosporidium sp e Cyclospora cayetanensis. Revista da Sociedade Brasileira de Medicina Tropical, v. 42, n. 3, p. 348-350, 2009. http://dx.doi.org/10.1590/S0037-86822009000300022

BRASIL. Ministério da Saúde. Sistema de Informação da Atenção à Saúde Indígena. 2015. Available in: http://portalsaude.saude.gov.br/index.php/oministerio/principal/secretarias/secretaria-sesai. Access in: Nov. 2016.

BREWER, G. J. Risks of copper and iron toxicity during aging in humans. Chemical Research in Toxicology, v. 23, n. 2, p. 319-326, 2009. http://dx.doi.org/10.1021/tx900338d

BURGUERA, M.; BURGUERA, J. L. Flow injection-electrothermal atomic absorption spectrometry for arsenic speciation using the Fleitmann reaction. Journal of Analytical $\begin{array}{lllllllll}\text { Atomic } & \text { Spectrometry, } & \text { v. } & 8, & \text { n. } & 2, & \text { p. } & 229-233,\end{array}$ http://dx.doi.org/10.1039/C7JA00275K

CARVAlHO, A. R. Processo de complexação do ferro em águas subterrâneas. Uma proposta de mudança da portaria 36 do Ministério da Saúde. Guarulhos: UnG, 2000.

COMPANHIA AMBIENTAL DO ESTADO DE SÃO PAULO - CETESB. Guia nacional de coleta e preservação de amostras: água, sedimento, comunidades aquáticas e efluentes líquidos. São Paulo: CETESB; Brasília: ANA, 2011.

DERISIO, J. C. Introdução ao controle da poluição ambiental. São Paulo, 1992.

FLEMMING, C. A.; TREVORS, J. T. Copper toxicity and chemistry in the environment: a review. Water, Air, \& Soil Pollution, v. 44, n. 1, p. 143-158, 1989. http://dx.doi.org/10.1007/BF00228784

GAETKE, L. M.; CHOW, C. K. Copper toxicity, oxidative stress, and antioxidant nutrients. Toxicology, v. 189, n. 1, p. 147-163, 2003. http://dx.doi.org/10.1016/S0300483X(03)00159-8

HORVAT, M. Mercury analysis and speciation in environmental samples. In: Global and regional mercury cycles: sources, fluxes and mass balances. In: BAEYENS, W.; EBINGHAUS, R.; VASILIEV, O. (Eds.). Netherlands: Springer, 1996. p. 1-31. http://dx.doi.org/10.1007/978-94-009-1780-4

LALOR, G. C. Review of cadmium transfers from soil to humans and its health effects in the Jamaican environment. Science of the Total Environment, v. 400, n. 1, p. 162-172, 2008. http://dx.doi.org/10.1016/j.scitotenv.2008.07.011

LAWRENCE, M. G.; GREIGA A.; COLLERSONA, K. D.; KAMBERA, B. S. Direct quantification of rare earth element concentrations in natural waters by ICP-MS. Applied $\begin{array}{lllllll}\text { geochemistry, } & \text { v. } & 21, & \text { n. } & 5, & \text { p. } & 839-848,\end{array}$ http://dx.doi.org/10.1016/j.apgeochem.2006.02.013

LEBEL, J.; MERGLER, D.; BRANCHES, F.; LUCOTTE, M.; AMORIM, M.; LARRIBE, F. et al. Neurotoxic effects of low-level methylmercury contamination in the Amazonian Basin. Environmental research, v. 79, n. 1, p. 20-32, 1998. http://dx.doi.org/10.1006/enrs.1998.3846

MARMOT, M. Achieving health equity: from root causes to fair outcomes. The Lancet, v. 370, n. 9593, p. 1153-1163, 2007. http://dx.doi.org/10.1016/S0140-6736(07)61385-3 
MELVILLE, F.; BURCHETT, M. Genetic variation in Avicennia marina in three estuaries of Sydney (Australia) and implications for rehabilitation and management. Marine Pollution Bulletin, v. 44, n. 6, p. 469-479, 2002. http://dx.doi.org/10.1016/S0025326X(01)00259-4

MERTZ, W. Trace elements in human and animal nutrition. Volume 2. [S.l.]: Elsevier, 2012.

NAKAMURA, E.; EGRY, E. Y.; CAMPOS, C. M. S.; NICHIATA, L. Y. I.; CHIESA, A. M.; TAKAHASHI, R. F. The potential of an instrument to identify social vulnerabilities and health needs: collective health knowledge and practices. Revista Latino-Americana de Enfermagem, v. 17, n. 2, p. 253-258, 2009. http://dx.doi.org/10.1590/S010411692009000200018

PATRICK, L. Lead toxicity, a review of the literature. Part 1: Exposure, evaluation, and treatment. Alternative Medicine Review, v. 11, n. 1, p. 2-22, 2006.

PRUSZKOWSKI, E.; BOSNAK, C. The Analysis of Drinking Waters by U. S. EPA Methods 200.8 Using the NexION 300Q/350Q ICP-MS in Standard Mode. Waltham: Perkin-Elmer, 2012.

ROGERS, W.; BALLANTYNE, A. Special populations: vulnerability and protection. Electronic Journal of Communication Information \& Innovation in Health, v. 2, n. Sup.1, p. 30-40, 2008. http://dx.doi.org/10.3395/reciis.v2.Sup1.207en

SANTOS, D. M.; BOSSINI, J. A. T.; PREUSSLER, K. H.; VASCONSELOS, E. C.; CARVALHO-NETO, F. S.; CARVALHO-FILHO, M. A. S. Avaliação de metais pesados na baía de Paranaguá, PR, Brasil, sob influência das atividades antrópicas. Journal of the Brazilian Society of Ecotoxicology, v. 1, n. 2, p. 157-160, 2006. http://dx.doi.org/10.5132/jbse.2006.02.013

SANTOS, E. C. O.; CÂMARA, V. M.; BRABO, E. S.; LOUREIRO, E. C. B.; JESUS, I. M.; FAYAL, K.; SAGICA, F. Avaliação dos níveis de exposição ao mercúrio entre índios Pakaanóva, Amazônia, Brasil. Cadernos de Saúde Pública, v. 19, n. 1, p. 199-206, 2003. http://dx.doi.org/10.1590/S0102-311X2003000100022

SANTOS, L. T. S. O. Caracterização de metais pesados das águas superficiais da bacia do Rio Subaé (Bahia). Geochimica Brasiliensis, v. 28, n. 2, p. 137-148, 2015. http://dx.doi.org/10.5327/Z0102-9800201400020003 
Table S1. Collection points, abbreviations, classification in terms of water source and geodetic coordinates.

\begin{tabular}{|c|c|c|c|c|}
\hline Description of the place & Abbreviation & Origin & Latitude & Longitude \\
\hline Well of capture Aldeia Vila Nova & AP1 & Groundwater & $16,53,10.7$ & $40,32,38.0$ \\
\hline Reservoir Aldeia Vila Nova & AP2 & Groundwater & $16,52,36.3$ & $40,33,56,6$ \\
\hline End of water network-Faucet-Posto Vila Nova & AP3 & Groundwater & $16,53,04.9$ & $40,32,36.4$ \\
\hline Umburana River & AP4 & Surface & $16,52,51.5$ & $40,32,26.8$ \\
\hline Stream Aldeia João Mineiro & AP5 & Surface & $16,53,03.7$ & $40,33,02.4$ \\
\hline Stream Aldeia Maravilha & AP6 & Surface & $16,52,28.0$ & $40,34,10.4$ \\
\hline Well of capture Aldeia Cachoeira & AP7 & Groundwater & $16,52,21.7$ & $40,34,16.1$ \\
\hline Reservoir Aldeia Cachoeira & AP8 & Groundwater & $16,52,04.4$ & $40,34,33.4$ \\
\hline End of water -Faucet-Aldeia Maravilha & AP9 & Groundwater & $16,52,36.3$ & $40,34,05.2$ \\
\hline Well of capture Principal-Riacho & AV1 & Surface & $17,37,45.28$ & $41,44,59.74$ \\
\hline Reservoir-Filtro Lento & AV2 & Surface & $17,37,42.27$ & $41,44,59.17$ \\
\hline Well/ Reservoir Health Post & AV3 & Groundwater & $17,37,40.70$ & $41,44,49.85$ \\
\hline End of water network-Faucet - Pinheiro School & AV4 & Surface 1 & $17,37,42.11$ & $41,44,57.08$ \\
\hline Lagoon & AV5 & Surface 1 & $17,37,43.29$ & $41,44,48.29$ \\
\hline Well of capture Aldeia Agua Boa & $\mathrm{AB} 1$ & Groundwater & $16,53,29.8$ & $40,36,13.4$ \\
\hline Reservoir Aldeia Agua Boa & AB2 & Groundwater & $16,53,08.7$ & $40,36,14.3$ \\
\hline End of water network-Faucet -Aldeia Pirino & AB3 & Groundwater & $16,52,28.7$ & $40,36,16.0$ \\
\hline Stream Aldeia João Bidé & $\mathrm{AB} 4$ & Surface & $16,52,35.1$ & $40,36,16.9$ \\
\hline Spring Agua Boa River & AB5 & Surface & $16,53,26.58$ & $40,36,54.19$ \\
\hline Stream Agua Boa- Ponte de Cimento & AB6 & Surface & $16,53,28.6$ & $40,36,51.9$ \\
\hline End of water-Spring A. Boa-Aldeia Luizinha & $\mathrm{AB} 7$ & Surface & $16,53,12.0$ & $40,36,52.6$ \\
\hline Lagoon Captation & AR1 & Surface & $17,56,35,0$ & $41,26,28,6$ \\
\hline Reservoir with Slow Filter & AR2 & Surface & $17,56,55,5$ & $41,26,30.7$ \\
\hline End of water network- Faucet last House & AR3 & Surface & $17,56,48.12$ & $41,26,54.24$ \\
\hline
\end{tabular}

Abbreviations: AP-Aldeia Pradinho, AB- Aldeia Água Boa, AV- Aldeia Verde (Ladainha) e ARAldeia Rafael (Topázio). 
Table S2. Metals with absolute concentrations in micrograms per liter $(\mu \mathrm{g} / \mathrm{L})$, in the three seasonal periods at twenty-four collection points in Maxakali Villages from January to July 2015.

\begin{tabular}{|c|c|c|c|c|c|c|c|c|c|c|c|c|c|c|c|}
\hline \multirow[t]{2}{*}{ Points } & \multicolumn{3}{|c|}{$\begin{array}{c}\text { Al (Aluminum) } \\
\text { VMP Sup:100 Sub: } 200\end{array}$} & \multicolumn{3}{|c|}{$\begin{array}{c}\text { Cr (Chromium) } \\
\text { VMP:50 }\end{array}$} & \multicolumn{3}{|c|}{$\begin{array}{l}\text { Fe (Iron) } \\
\text { VMP:300 }\end{array}$} & \multicolumn{3}{|c|}{$\begin{array}{c}\text { Cu (Copper) } \\
\text { VMP: Sup: 9 Sub: } 2000\end{array}$} & \multicolumn{3}{|c|}{$\begin{array}{c}\text { As (Arsenic) } \\
\text { VMP: } 10\end{array}$} \\
\hline & $1^{\mathrm{a}}$ & $2^{\mathrm{a}}$ & $3^{a}$ & $\mathbf{1}^{\mathrm{a}}$ & $2^{\mathrm{a}}$ & $3^{\mathrm{a}}$ & $\mathbf{1}^{\mathrm{a}}$ & $2^{\mathrm{a}}$ & $3^{\mathrm{a}}$ & $\mathbf{1}^{\mathrm{a}}$ & $2^{\mathrm{a}}$ & $3^{\mathrm{a}}$ & $\mathbf{1}^{\mathrm{a}}$ & $2^{a}$ & $3^{a}$ \\
\hline AP1* & $<\mathrm{LOQ}$ & 121,05 & 25,38 & $<\mathrm{LOQ}$ & 39,75 & 16,01 & $1088,97 \uparrow$ & $<\mathrm{LOQ}$ & $10725,24 \uparrow$ & $<$ LOQ & $<\mathrm{LOQ}$ & 9,19 & $<\mathrm{LOQ}$ & $167,01 \uparrow$ & $15,32 \uparrow$ \\
\hline AP2* & $<\mathrm{LOQ}$ & 100,43 & 12,42 & 2,72 & 33,92 & 10,6 & $1768,3 \uparrow$ & $<\mathrm{LOQ}$ & 39 & $<\mathrm{LOQ}$ & $<\mathrm{LOQ}$ & 3,4 & $<\mathrm{LOQ}$ & $154,41 \uparrow$ & 7,77 \\
\hline AP3* & $<\mathrm{LOQ}$ & 86,75 & 11,07 & $<\mathrm{LOQ}$ & 31,69 & 9,43 & $1015,51 \uparrow$ & $<\mathrm{LOQ}$ & 32,59 & $<$ LOQ & $<\mathrm{LOQ}$ & 2,33 & $<\mathrm{LOQ}$ & $146,6 \uparrow$ & 8,03 \\
\hline $\mathbf{A P 4}$ ** & $49206 \uparrow$ & 97,4 & 50,66 & $56,97 \uparrow$ & 30,99 & 9,5 & $88664,74 \uparrow$ & $<\mathrm{LOQ}$ & $959,96 \uparrow$ & $\mathbf{3 7 , 8 8} \uparrow$ & $<\mathrm{LOQ}$ & 3,18 & 4,84 & $147,41 \uparrow$ & 7,23 \\
\hline AP5** & $9018,45 \uparrow$ & $148,57 \uparrow$ & $269,22 \uparrow$ & 7,93 & 43,67 & 9,76 & $43373,32 \uparrow$ & 118,94 & $2487,27 \uparrow$ & 8,57 & $<\mathrm{LOQ}$ & 3,28 & $<\mathrm{LOQ}$ & $178,36 \uparrow$ & 7,64 \\
\hline AP6** & 39,46 & $158,42 \uparrow$ & $124,31 \uparrow$ & $<\mathrm{LOQ}$ & 44,72 & 12,17 & $2382,9 \uparrow$ & 63,49 & 245,25 & $<\mathrm{LOQ}$ & $<\mathrm{LOQ}$ & $11,04 \uparrow$ & $<\mathrm{LOQ}$ & $182,11 \uparrow$ & 7,49 \\
\hline AP7* & $<\mathrm{LOQ}$ & 113,3 & 23,71 & $<\mathrm{LOQ}$ & 32,59 & 9,87 & $623,11 \uparrow$ & $2551,11 \uparrow$ & $929,66 \uparrow$ & $<\mathrm{LOQ}$ & $<\mathrm{LOQ}$ & 3,35 & $<\mathrm{LOQ}$ & $138,27 \uparrow$ & 7,39 \\
\hline AP8* & $<\mathrm{LOQ}$ & 110,77 & 63,92 & 2,03 & 33,18 & 11,14 & $7409,94 \uparrow$ & $<\mathrm{LOQ}$ & $\mathbf{8 9 9 , 7 3 \uparrow}$ & 20,48 & $<\mathrm{LOQ}$ & 10,7 & 2,02 & $147,54 \uparrow$ & 7,47 \\
\hline AP9* & $<\mathrm{LOQ}$ & 120,03 & 19 & $<\mathrm{LOQ}$ & 36,61 & 12,28 & $2896,71 \uparrow$ & 105,04 & $2097,46 \uparrow$ & $<\mathrm{LOQ}$ & $<\mathrm{LOQ}$ & 12,16 & $<\mathrm{LOQ}$ & $158,87 \uparrow$ & 7,5 \\
\hline AB1* & $<\mathrm{LOQ}$ & 136,26 & $424,29 \uparrow$ & $<\mathrm{LOQ}$ & 42,1 & 10,34 & $1317,48 \uparrow$ & 98,17 & $21849,92 \uparrow$ & $<\mathrm{LOQ}$ & $<\mathrm{LOQ}$ & 9,25 & $<\mathrm{LOQ}$ & $165,32 \uparrow$ & 7,44 \\
\hline AB2* & $<\mathrm{LOQ}$ & 92,4 & 171,69 & $<\mathrm{LOQ}$ & 33,53 & 9,82 & $1404,2 \uparrow$ & 36,66 & $959,91 \uparrow$ & $<\mathrm{LOQ}$ & $<\mathrm{LOQ}$ & 3,09 & $<\mathrm{LOQ}$ & $157,32 \uparrow$ & 7,26 \\
\hline AB3* & $<\mathrm{LOQ}$ & 104,93 & 142,91 & $<\mathrm{LOQ}$ & 36,86 & 9,72 & $1579,88 \uparrow$ & $<\mathrm{LOQ}$ & $696,48 \uparrow$ & $<\mathrm{LOQ}$ & $<\mathrm{LOQ}$ & 2,7 & $<\mathrm{LOQ}$ & $161,79 \uparrow$ & 7,19 \\
\hline $\mathbf{A B} 4 * *$ & $7238,83 \uparrow$ & 86,6 & 53,25 & 5,53 & 31,4 & 9,6 & $25078,13 \uparrow$ & $<\mathrm{LOQ}$ & 107,83 & $<\mathrm{LOQ}$ & $<\mathrm{LOQ}$ & 5,52 & $<\mathrm{LOQ}$ & $152,25 \uparrow$ & 7,06 \\
\hline $\mathbf{A B 5}^{* *}$ & $<\mathrm{LOQ}$ & $101,25 \uparrow$ & 4,51 & $<\mathrm{LOQ}$ & 34,58 & 9,62 & $1593,73 \uparrow$ & $<\mathrm{LOQ}$ & 76,6 & $<\mathrm{LOQ}$ & $<\mathrm{LOQ}$ & 6,59 & $<\mathrm{LOQ}$ & $155,26 \uparrow$ & 7,03 \\
\hline AB6** & $<\mathrm{LOQ}$ & 98,25 & 46,93 & $<\mathrm{LOQ}$ & 34,61 & 10,78 & $3029,34 \uparrow$ & $<\mathrm{LOQ}$ & $503,41 \uparrow$ & $<\mathrm{LOQ}$ & $<\mathrm{LOQ}$ & $11,44 \uparrow$ & $<\mathrm{LOQ}$ & $159,32 \uparrow$ & 7,05 \\
\hline $\mathbf{A B} 7 * *$ & $<\mathrm{LOQ}$ & $114,45 \uparrow$ & 32,76 & $<\mathrm{LOQ}$ & 39,81 & 10,96 & $1763,73 \uparrow$ & $<\mathrm{LOQ}$ & $323,96 \uparrow$ & $<\mathrm{LOQ}$ & $<\mathrm{LOQ}$ & $13,79 \uparrow$ & $<\mathrm{LOQ}$ & $166,8 \uparrow$ & 7,02 \\
\hline AV1** & $<\mathrm{LOQ}$ & $100,09 \uparrow$ & $146,83 \uparrow$ & $<\mathrm{LOQ}$ & 32,7 & 42,29 & $303,49 \uparrow$ & $<\mathrm{LOQ}$ & $<\mathrm{LOQ}$ & $<\mathrm{LOQ}$ & $<\mathrm{LOQ}$ & $<\mathrm{LOQ}$ & $<\mathrm{LOQ}$ & $146,52 \uparrow$ & $169,42 \uparrow$ \\
\hline AV2** & $<\mathrm{LOQ}$ & $103,55 \uparrow$ & $122,37 \uparrow$ & $<\mathrm{LOQ}$ & 32,41 & 34,45 & 270,12 & $<\mathrm{LOQ}$ & $<\mathrm{LOQ}$ & $<\mathrm{LOQ}$ & $<\mathrm{LOQ}$ & $<\mathrm{LOQ}$ & $<\mathrm{LOQ}$ & $143,66 \uparrow$ & $145,88 \uparrow$ \\
\hline AV3* & $<\mathrm{LOQ}$ & 133,49 & 112,7 & $<\mathrm{LOQ}$ & 33,94 & 33,89 & $4813,29 \uparrow$ & 112,61 & $<\mathrm{LOQ}$ & $<\mathrm{LOQ}$ & $<\mathrm{LOQ}$ & $<\mathrm{LOQ}$ & $<\mathrm{LOQ}$ & $152,6 \uparrow$ & $144,9 \uparrow$ \\
\hline AV4** & $828,39 \uparrow$ & $110,64 \uparrow$ & $102,69 \uparrow$ & $<\mathrm{LOQ}$ & 35,47 & 35,33 & $7340,97 \uparrow$ & $<\mathrm{LOQ}$ & $<\mathrm{LOQ}$ & $<\mathrm{LOQ}$ & $<\mathrm{LOQ}$ & $<\mathrm{LOQ}$ & $<\mathrm{LOQ}$ & $156,16 \uparrow$ & $154,86 \uparrow$ \\
\hline AV5** & $178,92 \uparrow$ & $108,32 \uparrow$ & $111,26 \uparrow$ & $<\mathrm{LOQ}$ & 33,49 & 34,84 & $13173,51 \uparrow$ & $<\mathrm{LOQ}$ & $<\mathrm{LOQ}$ & $<\mathrm{LOQ}$ & $<\mathrm{LOQ}$ & $<\mathrm{LOQ}$ & $<\mathrm{LOQ}$ & $151,65 \uparrow$ & $156,34 \uparrow$ \\
\hline AR1** & $<\mathrm{LOQ}$ & $106,99 \uparrow$ & $131,59 \uparrow$ & $<\mathrm{LOQ}$ & 34,97 & 35,98 & 82,19 & $662,2 \uparrow$ & $452,98 \uparrow$ & $<\mathrm{LOQ}$ & $<\mathrm{LOQ}$ & $<\mathrm{LOQ}$ & $<\mathrm{LOQ}$ & $145,44 \uparrow$ & $148,66 \uparrow$ \\
\hline $\mathbf{A R} 2 * *$ & 48,19 & $115,52 \uparrow$ & $109,99 \uparrow$ & $<\mathrm{LOQ}$ & 33,59 & 36,73 & $13252,56 \uparrow$ & 203,05 & 274,72 & $<\mathrm{LOQ}$ & $<$ LOQ & $<\mathrm{LOQ}$ & $<\mathrm{LOQ}$ & $144,73 \uparrow$ & $154,96 \uparrow$ \\
\hline AR3** & 25,16 & $114,2 \uparrow$ & $111,69 \uparrow$ & $<\mathrm{LOQ}$ & 34,84 & 35,54 & $12296,57 \uparrow$ & 48,67 & $<\mathrm{LOQ}$ & $<\mathrm{LOQ}$ & $<\mathrm{LOQ}$ & $<\mathrm{LOQ}$ & $<\mathrm{LOQ}$ & $144,25 \uparrow$ & $148,11 \uparrow$ \\
\hline
\end{tabular}

Rev. Ambient. Água vol. 14 n. 1, e2215 - Taubaté 2019 


\begin{tabular}{|c|c|c|c|c|c|c|c|c|c|c|c|c|c|c|c|c|c|}
\hline \multicolumn{18}{|c|}{ Continued... } \\
\hline \multirow[t]{2}{*}{ Points } & \multicolumn{3}{|c|}{$\begin{array}{l}\text { Se (Selenium) } \\
\text { VMP: } 10\end{array}$} & \multicolumn{3}{|c|}{$\begin{array}{l}\text { St (Strontium) } \\
\text { VMP: } 1000\end{array}$} & \multicolumn{3}{|c|}{$\begin{array}{c}\text { Cd (Cadmium) } \\
\text { VMP Sup: } 1 \text { Sub: } 5 \\
\end{array}$} & \multicolumn{3}{|c|}{$\begin{array}{c}\text { Ba (Barium) } \\
\text { VMP Sup: 70 Sub: } 700\end{array}$} & \multicolumn{3}{|c|}{$\begin{array}{l}\text { Pb (Lead) } \\
\text { VMP: } 10\end{array}$} & \multicolumn{2}{|c|}{$\begin{array}{c}\text { Hg (Mercury) } \\
\text { VMP: Sup: 0,2 Sub: } 1\end{array}$} \\
\hline & $1^{a}$ & $2^{a}$ & $3^{a}$ & $1^{a}$ & $2^{\mathrm{a}}$ & $3^{a}$ & $1^{a}$ & $2^{\mathrm{a}}$ & $3^{\mathrm{a}}$ & $\mathbf{1}^{\mathrm{a}}$ & $2^{\mathrm{a}}$ & $3^{a}$ & $1^{a}$ & $2^{\mathrm{a}}$ & $3^{a}$ & $1^{a}$ & $2^{\mathrm{a}}$ \\
\hline AP1* & $<\mathrm{LOQ}$ & $<\mathrm{LOQ}$ & 6,44 & 286,94 & 0,19 & 120,89 & $<\mathrm{LOQ}$ & $<\mathrm{LOQ}$ & $5,15 \uparrow$ & 50,88 & 4,23 & 61,8 & $<\mathrm{LOQ}$ & $<\mathrm{LOQ}$ & $11,47 \uparrow$ & $<\mathrm{LOQ}$ & $2,844 \uparrow$ \\
\hline AP2* & $<\mathrm{LOQ}$ & $<\mathrm{LOQ}$ & 5,96 & 260,79 & 24,47 & 84,84 & $<\mathrm{LOQ}$ & $<\mathrm{LOQ}$ & $5,09 \uparrow$ & 68,91 & 13,31 & 36,07 & $<\mathrm{LOQ}$ & $<\mathrm{LOQ}$ & 8,43 & $<\mathrm{LOQ}$ & 0,423 \\
\hline AP3* & $<\mathrm{LOQ}$ & $<\mathrm{LOQ}$ & 6,34 & 173,99 & 22,72 & 111,53 & $<\mathrm{LOQ}$ & $<\mathrm{LOQ}$ & $5,08 \uparrow$ & 50,98 & 11,83 & 41,99 & $<\mathrm{LOQ}$ & $<\mathrm{LOQ}$ & 8,38 & $<\mathrm{LOQ}$ & $17,9 \uparrow$ \\
\hline $\mathbf{A P 4} * *$ & $<\mathrm{LOQ}$ & $<\mathrm{LOQ}$ & 5,53 & 114,26 & 27,69 & 25,04 & $<$ LOQ & $<\mathrm{LOQ}$ & $5,09 \uparrow$ & $956,59 \uparrow$ & 14,6 & 30,54 & $52,16 \uparrow$ & $<\mathrm{LOQ}$ & 8,52 & $<\mathrm{LOQ}$ & $16,57 \uparrow$ \\
\hline AP5** & $<\mathrm{LOQ}$ & $<\mathrm{LOQ}$ & 6,32 & 90,1 & 2,75 & 68,98 & $<$ LOQ & $<\mathrm{LOQ}$ & $5,08 \uparrow$ & $391,1 \uparrow$ & 14,02 & 67,1 & $19,38 \uparrow$ & $<\mathrm{LOQ}$ & 8,61 & $<\mathrm{LOQ}$ & $15,64 \uparrow$ \\
\hline AP6** & $<\mathrm{LOQ}$ & $<\mathrm{LOQ}$ & 5,86 & 11,41 & 22,29 & 46,61 & $<\mathrm{LOQ}$ & $<\mathrm{LOQ}$ & $5,09 \uparrow$ & 18,46 & 34,31 & 29,25 & $<\mathrm{LOQ}$ & $<\mathrm{LOQ}$ & 8,73 & $<\mathrm{LOQ}$ & $15,24 \uparrow$ \\
\hline $\mathbf{A P 7} \mathbf{7}^{*}$ & $<\mathrm{LOQ}$ & $<\mathrm{LOQ}$ & 5,54 & 175,61 & 22,47 & 130,8 & $<$ LOQ & $<\mathrm{LOQ}$ & $5,09 \uparrow$ & 55,64 & 48,6 & 48,48 & $<\mathrm{LOQ}$ & $<\mathrm{LOQ}$ & 9,36 & $<\mathrm{LOQ}$ & $14,98 \uparrow$ \\
\hline AP8* & $<\mathrm{LOQ}$ & $<\mathrm{LOQ}$ & 6,04 & 131,25 & 31,25 & 166,29 & $<$ LOQ & $<\mathrm{LOQ}$ & $5,09 \uparrow$ & 61,35 & 14,53 & 56,72 & $<\mathrm{LOQ}$ & $<\mathrm{LOQ}$ & 9,05 & $<\mathrm{LOQ}$ & $14,85 \uparrow$ \\
\hline AP9* & $<\mathrm{LOQ}$ & $<\mathrm{LOQ}$ & 5,88 & 169,21 & 34,44 & 102,6 & $<$ LOQ & $<\mathrm{LOQ}$ & $5,07 \uparrow$ & 139,83 & 17,02 & 31,14 & $<\mathrm{LOQ}$ & $<\mathrm{LOQ}$ & 8,28 & $<\mathrm{LOQ}$ & $14,61 \uparrow$ \\
\hline AB1* & $<\mathrm{LOQ}$ & $<\mathrm{LOQ}$ & 5,46 & 11,4 & 16,21 & 68,86 & $<$ LOQ & $<\mathrm{LOQ}$ & $5,07 \uparrow$ & 19,61 & 21,81 & 205,95 & $<\mathrm{LOQ}$ & $<\mathrm{LOQ}$ & $12,52 \uparrow$ & $<\mathrm{LOQ}$ & $14,26 \uparrow$ \\
\hline$A B 2 *$ & $<\mathrm{LOQ}$ & $<\mathrm{LOQ}$ & 5,48 & 0,29 & 13,81 & 64,81 & $<$ LOQ & $<\mathrm{LOQ}$ & $5,07 \uparrow$ & 14,6 & 36,59 & 77,44 & $<\mathrm{LOQ}$ & $<\mathrm{LOQ}$ & 8,26 & $<\mathrm{LOQ}$ & $14,16 \uparrow$ \\
\hline AB3* & $<$ LOQ & $<$ LOQ & 5,45 & 19,33 & 11,99 & 66,84 & $<\mathrm{LOQ}$ & $<$ LOQ & $5,07 \uparrow$ & 27,13 & 28,12 & 82,47 & $<\mathrm{LOQ}$ & $<$ LOQ & 8,16 & $<$ LOQ & $14 \uparrow$ \\
\hline $\mathbf{A B} 4 * *$ & $<\mathrm{LOQ}$ & $<\mathrm{LOQ}$ & 5,19 & 76,97 & 10,78 & 21,9 & $<\mathrm{LOQ}$ & $<\mathrm{LOQ}$ & $5,07 \uparrow$ & $236,6 \uparrow$ & 25,02 & 17,61 & 0,81 & $<\mathrm{LOQ}$ & 8,24 & $<\mathrm{LOQ}$ & $14,05 \uparrow$ \\
\hline $\mathbf{A B 5}^{* *}$ & $<\mathrm{LOQ}$ & $<\mathrm{LOQ}$ & 5,5 & 64,52 & 1,4 & 16,27 & $<\mathrm{LOQ}$ & $<\mathrm{LOQ}$ & $5,07 \uparrow$ & $74,63 \uparrow$ & 13,02 & 12,94 & $<\mathrm{LOQ}$ & $<\mathrm{LOQ}$ & 8,22 & $<\mathrm{LOQ}$ & $14,11 \uparrow$ \\
\hline $\mathbf{A B} 6^{* * *}$ & $<\mathrm{LOQ}$ & $<\mathrm{LOQ}$ & 5,55 & 69,14 & $<\mathrm{LOQ}$ & 21,98 & $<$ LOQ & $<\mathrm{LOQ}$ & $5,07 \uparrow$ & $89,93 \uparrow$ & 5,19 & 22,81 & $<\mathrm{LOQ}$ & 8,66 & 8,38 & $<\mathrm{LOQ}$ & $13,83 \uparrow$ \\
\hline $\mathbf{A B} 7 * *$ & $<\mathrm{LOQ}$ & $<\mathrm{LOQ}$ & 5,53 & 68,16 & $<\mathrm{LOQ}$ & 21,07 & $<$ LOQ & $<\mathrm{LOQ}$ & $5,08 \uparrow$ & $74,87 \uparrow$ & 2,91 & 17,73 & $<\mathrm{LOQ}$ & $<\mathrm{LOQ}$ & 8,49 & $<\mathrm{LOQ}$ & $13,69 \uparrow$ \\
\hline AV1** & $<\mathrm{LOQ}$ & $<\mathrm{LOQ}$ & $<\mathrm{LOQ}$ & 22,49 & 28,85 & 0,98 & $<\mathrm{LOQ}$ & $<\mathrm{LOQ}$ & $<\mathrm{LOQ}$ & 59,63 & 8,51 & 15,66 & $<\mathrm{LOQ}$ & $<\mathrm{LOQ}$ & $<\mathrm{LOQ}$ & $<\mathrm{LOQ}$ & $<\mathrm{LOQ}$ \\
\hline AV2** & $<\mathrm{LOQ}$ & $<$ LOQ & $<\mathrm{LOQ}$ & 24,99 & $<\mathrm{LOQ}$ & $<\mathrm{LOQ}$ & $<\mathrm{LOQ}$ & $<\mathrm{LOQ}$ & $<\mathrm{LOQ}$ & 64,82 & 0,97 & 0,57 & $<\mathrm{LOQ}$ & $<\mathrm{LOQ}$ & $<\mathrm{LOQ}$ & $<\mathrm{LOQ}$ & $<\mathrm{LOQ}$ \\
\hline AV3* & $<\mathrm{LOQ}$ & $<\mathrm{LOQ}$ & $<\mathrm{LOQ}$ & 23,24 & $<\mathrm{LOQ}$ & $<\mathrm{LOQ}$ & $<\mathrm{LOQ}$ & $<\mathrm{LOQ}$ & $<\mathrm{LOQ}$ & 75,34 & 4,81 & 0,13 & $<\mathrm{LOQ}$ & $<\mathrm{LOQ}$ & $<\mathrm{LOQ}$ & $<\mathrm{LOQ}$ & $<\mathrm{LOQ}$ \\
\hline $\operatorname{AV4} 4^{* *}$ & $<\mathrm{LOQ}$ & $<\mathrm{LOQ}$ & $<\mathrm{LOQ}$ & 30,28 & $<\mathrm{LOQ}$ & $<\mathrm{LOQ}$ & $<\mathrm{LOQ}$ & $<\mathrm{LOQ}$ & $<\mathrm{LOQ}$ & 44,92 & 13,1 & 12,04 & $<\mathrm{LOQ}$ & $<\mathrm{LOQ}$ & $<\mathrm{LOQ}$ & $<\mathrm{LOQ}$ & $<\mathrm{LOQ}$ \\
\hline AV5** & $<\mathrm{LOQ}$ & $<\mathrm{LOQ}$ & $<\mathrm{LOQ}$ & 38,08 & $<\mathrm{LOQ}$ & $<\mathrm{LOQ}$ & $<$ LOQ & $<\mathrm{LOQ}$ & $<\mathrm{LOQ}$ & 50,64 & 1,73 & $-0,54$ & $<\mathrm{LOQ}$ & $<\mathrm{LOQ}$ & $<\mathrm{LOQ}$ & $<\mathrm{LOQ}$ & $<\mathrm{LOQ}$ \\
\hline AR1** & $<\mathrm{LOQ}$ & $<\mathrm{LOQ}$ & $<\mathrm{LOQ}$ & $<\mathrm{LOQ}$ & 3,35 & $<\mathrm{LOQ}$ & $<\mathrm{LOQ}$ & $<\mathrm{LOQ}$ & $<\mathrm{LOQ}$ & 37,86 & 0,65 & 2,41 & $<\mathrm{LOQ}$ & $<\mathrm{LOQ}$ & $<$ LOQ & $<\mathrm{LOQ}$ & $<\mathrm{LOQ}$ \\
\hline$A R 2 * *$ & $<\mathrm{LOQ}$ & $<\mathrm{LOQ}$ & $<\mathrm{LOQ}$ & 28,27 & $<\mathrm{LOQ}$ & $<\mathrm{LOQ}$ & $<\mathrm{LOQ}$ & $<\mathrm{LOQ}$ & $<\mathrm{LOQ}$ & 47,54 & 7,87 & 10,41 & $<\mathrm{LOQ}$ & $<\mathrm{LOQ}$ & $<\mathrm{LOQ}$ & $<\mathrm{LOQ}$ & $<\mathrm{LOQ}$ \\
\hline $\mathbf{A R 3}^{* * *}$ & $<\mathrm{LOQ}$ & $<\mathrm{LOQ}$ & $<\mathrm{LOQ}$ & 25,45 & $<\mathrm{LOQ}$ & $<\mathrm{LOQ}$ & $<\mathrm{LOQ}$ & $<\mathrm{LOQ}$ & $<\mathrm{LOQ}$ & 47,12 & 11,99 & 11,03 & $<\mathrm{LOQ}$ & $<\mathrm{LOQ}$ & $<\mathrm{LOQ}$ & $<\mathrm{LOQ}$ & $<\mathrm{LOQ}$ \\
\hline
\end{tabular}

AP1-AP9: collection points in the village Pradinho, AB1-AB7- Aldeia Agua Boa, AV1-AV5- Aldeia Verde, AR1-AR3- Aldeia Rafael; Collection: 1st (January / 2015), 2nd (April / 2015) and 3rd (July / 2015). VMP: maximum value allowed, Ordinance 2914/2011, resolution CONAMA: 357/2005 and 396/2008; $\uparrow$ Above VMP., SUP: surface waters, SUB- groundwater, * groundwater points, ** surface water points, (LOQ) limit of quantification. 